\title{
Complete genome sequence of Roseophage vB_DshP-R1, which infects Dinoroseobacter shibae DFL12
}

Jianda Ji, Rui Zhang ${ }^{*}$ and Nianzhi Jiao*

\begin{abstract}
The Roseophages, a group of marine viruses that uniquely infect the Roseobacter clade of bacteria, play a significant role in marine ecosystems. Here we present a complete genomic sequence of an N4 phage ' $v B$ _DshP-R1', which infects Dinoroseobacter shibae DFL12, together with its structural and genomic features. vB_DshP-R1 has an $\sim 75 \mathrm{~nm}$ diameter icosahedral structure and a complete genome of 75,028 bp. This is the first genome sequence of a lytic phage of the genus Dinoroseobacter.
\end{abstract}

Keywords: Roseophage, N4 phage, Dinoroseobacter shibae, Aquatic, Virus

\section{Introduction}

The Roseobacter clade is representative of the most abundant bacteria in the oceans of the world, typically accounting for up to $25 \%$ of all marine microbial communities [1-3]. Roseobacters are versatile in their metabolism, employing diverse catalytic processes in a range of environmentally relevant reactions, especially in the marine carbon, nitrogen and sulfur cycles [4-6]. Previous studies indicate that many species in this clade are symbionts with diverse phytoplankton [7]. Dinoroseobacter shibae DFL12 [8], the only species of the genus Dinoroseobacter of the Roseobacter clade, is an epibiont of the alga Prorocentrum lima, which can cause diarrhetic shellfish poisoning during red tides [9] and which was completely sequenced in 2010 [10]. D. shibae DFL12 is widely studied and found to develop ecologically diverse adaptations in marine environments, such as activating bacteriochlorophyll for lightdriven ATP synthesis [11], performing alternative routes in glucose catabolism [12], adjusting the energetic state to the oxygen regimen [13], improving algal metabolic activities [14] and presumably using an adaptive viral defense strategy (CRISPR/Cas systems) [10], discovered in many bacteria and archaea $[15,16]$. D. shibae DFL12 appears to have two distinct CRISPR/Cas systems in its genome [10]. On some occasions, implementation of this mechanism

\footnotetext{
* Correspondence: ruizhang@xmu.edu.cn; jiao@xmu.edu.cn

State Key Laboratory of Marine Environmental Science, Institute of Marine Microbes and Ecospheres, Xiamen University, Xiamen, PR, China
}

depends on the existing spacers of bacterial genomes that are located in these CRISPR/Cas systems and are highly similar to the genomic sequences of infective phages [15]. When the host packs or inserts such spacers in the defense systems, CRISPR-associated genes activate and disrupt replication of the foreign phage DNA in host cells. Recently, researchers have found some bacteriophage genes that counteract the CRISPR/Cas systems in Pseudomonas aeruginosa [17]. It is interesting to isolate and characterize the phage infecting this type of bacterium to see whether they also develop such an analogous function.

Roseophages specifically infecting the ubiquitous Roseobacter clade were recently characterized [18]. Only a few Roseophage genomes are sequenced to date, including those of Roseobacter SIO67 [18,19], Roseobacter denitrificans OCh114 [20], Silicibacter pomeroyi DSS-3, Sulfitobacter sp. EE-36 [21], Celeribacter [22] and Roseovarius. Interestingly, several N4 phages, originally exhibiting the specificity of lysing Escherichia coli [23,24], were recently isolated and identified from marine environments. The N4 phages belong to the Podoviridae and contain the unique characteristic of a large vRNAP gene packed in the capsids [25]. However, there are many unknown proteins present in N4 genomes or Roseophages and publications about these phages from marine environments are rare. We isolated a new N4 phage (named vB_DshP-R1) in 2012 from coastal surface seawater and found that it infected D. shibae DFL12. The genomic information 
indicated that it belonged to the N4 phages, and details of its genomic features and annotations are described below.

\section{Virus information}

Phage vB_DshP-R1 was isolated from surface water off the coast of Xiamen, China. It is a lytic phage, forming $~ 4-$ mm-diameter plaques after infection of $D$. shibae DFL12. Electron microscopy of purified phage particles (Figure 1) showed that vB_DshP-R1 possessed an icosahedral capsid $(\sim 75 \mathrm{~nm}$ in diameter) and a distinguishable short tail ( $\sim 35 \mathrm{~nm}$ length). It encapsulated a linear double-stranded DNA genome of $75,028 \mathrm{bp}$, with a remarkably large vRNAP gene. This vRNAP is a unique feature in N4 phages putatively conducting early transcription of infective processes. Aligning DNA polymerases of all N4 phages, which are commonly applied as one of the viral phylogenetic markers [26,27], phage vB_DshP-R1 is shown to cluster closely with four marine N4 Roseophages (Figure 2). Those phages were isolated from the hosts Silicibacter pomeroyi DSS-3, Sulfitobacter sp. EE-36, Roseovarius sp. 217 and Roseovarius nubinhibens. Phage
N4 was newly discovered in marine environments in 2009 and its hosts, as described above, were all within the Roseobacter clade, including D. shibae DFL12 in our study. All these phages are lytic and almost all were isolated from the surface seawater of harbors or coastal areas. A summary of their isolation and general phylogenetic features is shown in Table 1.

\section{Genome sequencing information}

\section{Genome project history}

The increasing number of investigations conducted recently illustrate that viruses (phages) play a very significant role in global ecosystems [31-33], including influences on ecology and evolution. Dinoroseobacter phage vB_DshP$\mathrm{R} 1$ is the first available genome sequence of a lytic phage infecting $D$. shibae. Genomic sequencing and analysis of this phage provides a chance to interpret virus-mediated processes and understand the interactions between its genetic capabilities with host, and in dynamic environments. D. shibae DFL12 employs a strong antiviral system in its genome [10], and the isolation of its phage provided a good host-phage system to investigate the infection

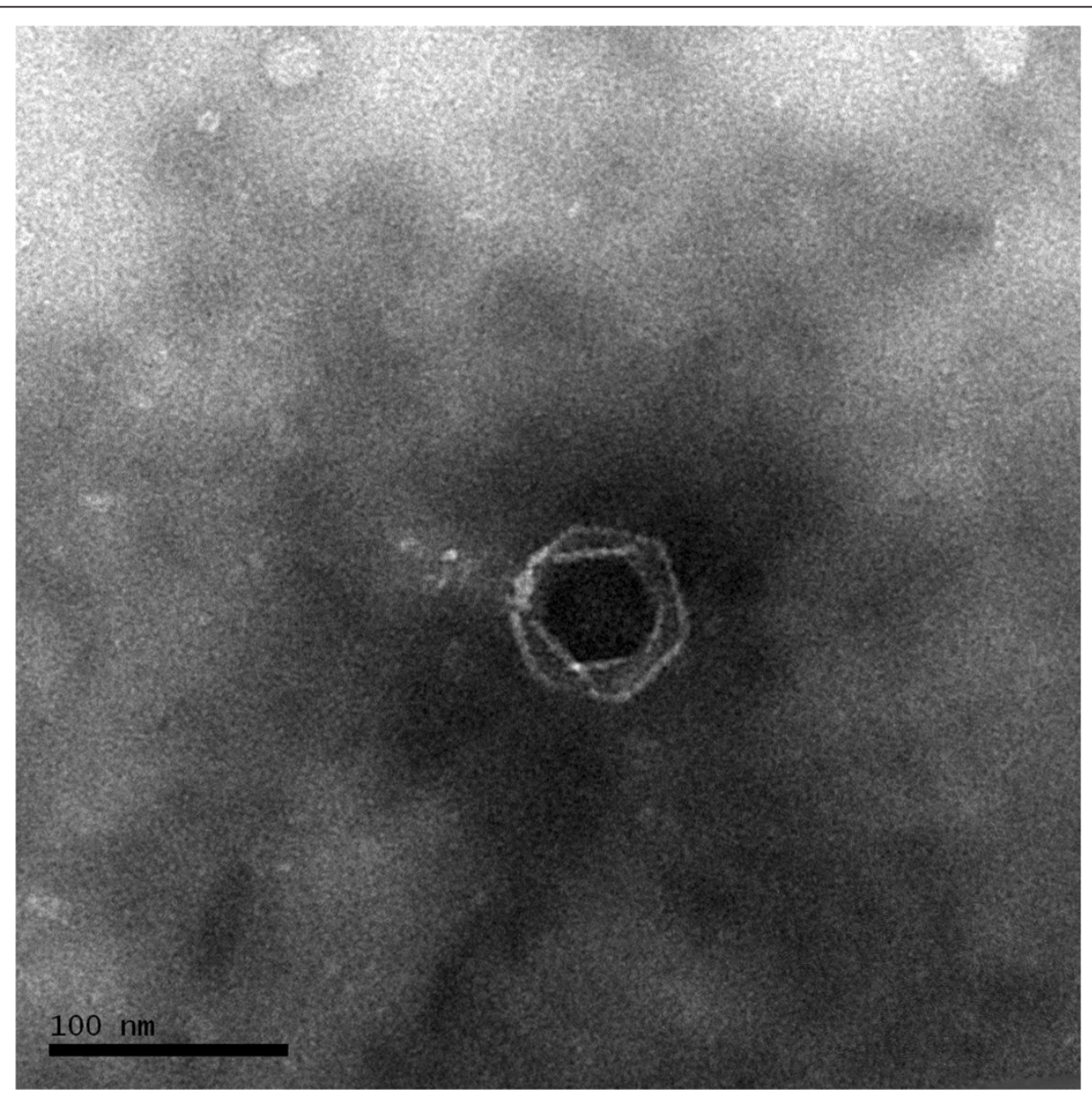

Figure 1 Transmission electron micrograph of Dinoroseobacter shibae DFL12 phage vB_DshP-R1 particles. Scale bar equals $100 \mathrm{~nm}$. 


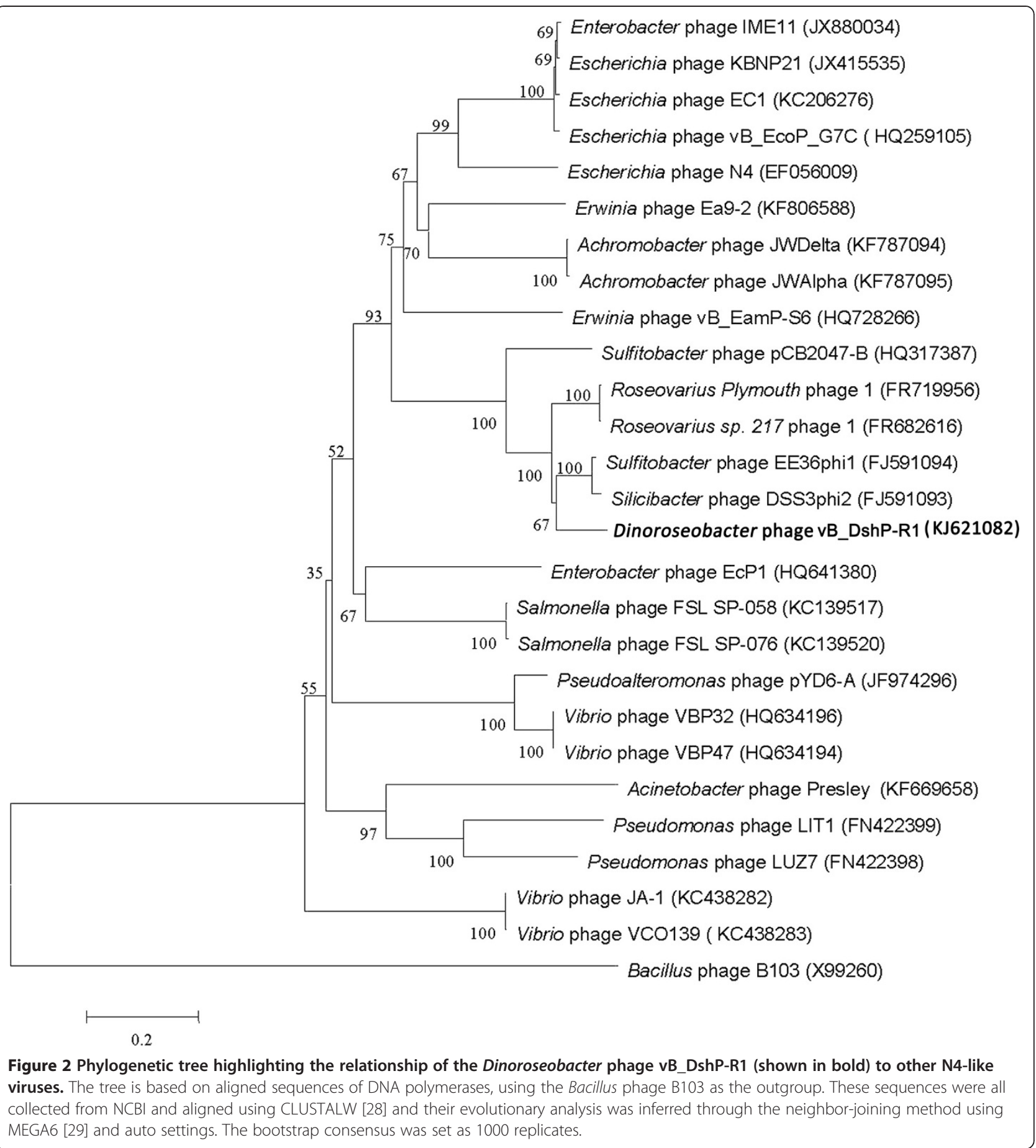

and anti-infection mechanism for CRISPR/Cas-harboring bacteria.

This genome project was recorded in GOLD (Genomes Online Database) and uploaded to the IMG (Integrated Microbial Genomes) system for genetic analysis together with the three gene naming methods described below. A summary of the project information is shown in Table 2.

\section{Growth conditions and DNA isolation}

D. shibae DFL12, grown in $0.22-\mu \mathrm{m}$ filtered and sterilized seawater supplemented with $1.0 \mathrm{gL}^{-1}$ of yeast extract and $1.0 \mathrm{gL}^{-1}$ of peptone, was used for phage isolation. Phage vB_DshP-R1 was isolated from the surface seawater collected on the coast of Xiamen, China (Table 1, Additional file 1) using a double agar overlay plaque assay described previously for the isolation of lytic phages $[21,34]$. 
Table 1 Classification and general features of Dinoroseobacter phage vB_DshP-R1

\begin{tabular}{|c|c|c|c|}
\hline MIGS ID & Property & Term & Evidence code $^{\mathrm{a}}$ \\
\hline & Current classification & Domain: viruses, dsDNA viruses, no RNA phage & TAS $[23,24]$ \\
\hline & & Phylum: unassigned & \\
\hline & & Class: unassigned & \\
\hline & & Order: Caudovirales & $\operatorname{TAS}[23,24]$ \\
\hline & & Family: Podoviridae & TAS $[23,24]$ \\
\hline & & Genus: N4likevirus & $\operatorname{TAS}[23,24]$ \\
\hline & & Species: unassigned & \\
\hline & & Strain: unassigned & \\
\hline & Particle shape & Icosahedral & IDA \\
\hline MIGS-6 & Habitat & Oceanic, coastal & IDA \\
\hline MIGS-15 & Biotic relationship & Obligate intracellular parasite of Dinoroseobacter shibae & IDA \\
\hline MIGS-14 & Pathogenicity & Lytic virus of Dinoroseobacter shibae & IDA \\
\hline MIGS-4 & Geographic location & Baicheng Harbor, Xiamen, China & IDA \\
\hline MIGS-5 & Sample collection time & May 22, 2012 & IDA \\
\hline MIGS-4.1 MIGS-4.2 & Latitude-Longitude & $24.43 \mathrm{~N}-118.08 \mathrm{E}$ & IDA \\
\hline MIGS-4.3 & Depth & Surface & IDA \\
\hline MIGS-4.4 & Altitude & & \\
\hline
\end{tabular}

${ }^{a}$ Evidence codes-IDA: Inferred from Direct Assay; TAS: Traceable Author Statement. The evidence codes are from of the Gene Ontology project [30].

Purification of phage DNA followed previous protocols with some modifications [21,35,36]. Approximately $600 \mathrm{~mL}$ phage lysates were prepared and added with DNase I and RNase A to a final concentration of $1 \mu \mathrm{gmL}^{-1}$. Then, $24 \mathrm{~g}$ $\mathrm{NaCl}$ was dissolved in the lysates and cooled at $4^{\circ} \mathrm{C}$. After about $1 \mathrm{~h}$, the mixed lysates were centrifuged at 10,000 $\times \mathrm{g}$ for $30 \mathrm{~min}$ at $4^{\circ} \mathrm{C}$ to remove the debris. Phage particles in the supernatant were precipitated with $10 \%(\mathrm{w} / \mathrm{v})$ dissolved polyethylene glycol 8000 . After $>8 \mathrm{~h}$, the mixture was pelleted at $10,000 \times \mathrm{g}$ for $30 \mathrm{~min}$ at $4{ }^{\circ} \mathrm{C}$ and then gently resuspended in $2 \mathrm{~mL}$ TM buffer (Tris- $\mathrm{HCl} 20 \mathrm{mM}$, MgSO4 $10 \mathrm{mM}, \mathrm{pH}$ 7.4). Phages were then ultracentrifuged in a $\mathrm{CsCl}$ gradient solutions at $200,000 \times \mathrm{g}$ for

Table 2 Project information

\begin{tabular}{lll}
\hline MIGS ID & Property & Term \\
\hline MIGS-31 & Finishing quality & Complete \\
MIGS-28 & Libraries used & One paired-end library \\
MIGS-29 & Sequencing platforms & Illumina Hiseq 2000 \\
MIGS-31.2 & Fold coverage & 1592× \\
MIGS-30 & Assemblers & SOAPdenovo version 1.05 \\
MIGS-32 & Gene calling method & GeneMarks version 4.7 (a), RAST \\
& & version 4.0, and ORF Finder \\
& Genome Database release & GenBank \\
& GenBank ID & KJ621082 \\
& GenBank Date of Release & April, 2014 \\
& GOLD ID & Gi0072148 \\
& Project relevance & Biological effects in aquatic areas \\
\end{tabular}

$24 \mathrm{~h}$ at $4^{\circ} \mathrm{C}$. Purified phage particles were collected and dialyzed twice in SM buffer overnight at $4^{\circ} \mathrm{C}$. Purified samples were stored in the dark at $4^{\circ} \mathrm{C}$. The genomic DNA of vB_DshP-R1 was purified following two rounds of treatment with phenol-chloroform [36]. Phage DNA was checked using PCR amplification of the bacterial 16S rRNA gene to eliminate contamination from host genomic DNA and prepared for sequencing as in the manufacturer's standard instructions.

\section{Genome sequencing and assembly}

The genome was sequenced at BGI-ShenzhenCo. using the traditional Illumina Hiseq 2000 platform following the manufacturer's instructions (Illumina, San Diego, CA, USA). The sequencing library was performed in accordance with the Hiseq 2000 instructions, which yielded $120 \mathrm{Mb}$ clean data reads after sets of rigorous filtration. De novo genome assembly of the resulting reads was performed using SOAPdenovo version 1.05 as described previously [37], and this provided $>1000 \times$ coverage of the genome.

\section{Genome annotation}

Prediction of genes in the genome was conducted and reconfirmed under three gene prediction programs: GeneMarks version 4.7 (a) program with phage option [38], RAST (Rapid Annotation using Subsystem Technology) server version 4.0 [39] and ORF Finder,the latter two using auto setting. The predicted ORFs were ascertained using two of the three methods and only 
homologies to known proteins $(\mathrm{E}$-value $<1 \mathrm{e}-5)$ were present in the annotations. The tRNA genes were searched using the tRNAscanSE tool [40]. Additional analysis of gene prediction and annotation was supplemented using the IMG platform developed by the Joint Genome Institute, Walnut Creek, CA, USA [41].

\section{Genome properties}

The properties and statistics of the genome are summarized in Tables 3, 4. vB_DshP-R1 encapsulated a linear dsDNA genome of 75,028 bp with $49.26 \%$ GC content, a total of 86 predicted coding sequences and two tRNA (encoding amino acids Ile and Pro). Of the predicted CDSs, more than half had low similarities (34\%-70\% identified in amino acid level) with sequences available in the NCBI database. In addition, 28 genes were assigned to conserved sequences, but only 16 were sorted into known functional categories. About $65 \%$ of the ORFs (more than $30 \%$ of the phage genome length) had no annotated feature, and 11 of them had no matches in the databases (Tables 3, 4, Additional file 2: Table S2).

\section{Insights from the genome sequence}

Profiles of transcription strategies in VB_DshP-R1

Transcriptional modules of the phage vB_DshP-R1 contain three vRNAPs in its virion particles (predicted proteins with $3,555,399$ and $263 \mathrm{aa}$ ). vRNAP is a unique feature in N4phages [24]. Analysis of sequencing features of the

Table 3 Nucleotide content and gene count levels of the genome

\begin{tabular}{lrr}
\hline Attribute & \multicolumn{2}{c}{ Genome (total) } \\
& Value & \% of total \\
\hline Size (bp) & 75,028 & 100.00 \\
G + C content (bp) & 36,959 & 49.26 \\
Coding region (bp) & 71,085 & 94.74 \\
Total genes ${ }^{\text {b }}$ & 88 & 100.00 \\
RNA genes & 2 & 2.33 \\
Protein-coding genes & 86 & 100.00 \\
Genes in paralog clusters & 6 & 6.98 \\
Genes assigned to CoGs & 16 & 18.60 \\
1 or more conserved domains & & \\
2 or more conserved domains & & 1.16 \\
3 or more conserved domains & & \\
4 or more conserved domains & & \\
Genes with signal peptides & 1 & \\
Genes with transmembrane helices & 9 & \\
Paralogous groups & 2 & \\
\hline
\end{tabular}

${ }^{\mathrm{a}}$ The total is based on either the size of the genome in base pairs or the total number of protein-coding genes in the annotated genome.

${ }^{\mathrm{b}}$ Also includes two RNA genes and six pseudogenes.
Table 4 Number of genes associated with the $\mathbf{2 5}$ general COG functional categories

\begin{tabular}{|c|c|c|c|}
\hline Code & Value & $\%$ of total ${ }^{\mathrm{a}}$ & Description \\
\hline J & 1 & 1.16 & Translation \\
\hline A & 0 & 0 & RNA processing and modification \\
\hline K & 1 & 1.16 & Transcription \\
\hline L & 3 & 3.49 & Replication, recombination and repair \\
\hline B & 0 & 0 & Chromatin structure and dynamics \\
\hline $\mathrm{D}$ & 1 & 1.16 & Cell cycle control, mitosis and meiosis \\
\hline Y & 0 & 0 & Nuclear structure \\
\hline V & 0 & 0 & Defense mechanisms \\
\hline $\mathrm{T}$ & 0 & 0 & Signal transduction mechanisms \\
\hline M & 0 & 0 & Cell wall/membrane biogenesis \\
\hline N & 0 & 0 & Cell motility \\
\hline Z & 0 & 0 & Cytoskeleton \\
\hline W & 0 & 0 & Extracellular structures \\
\hline U & 0 & 0 & Intracellular trafficking and secretion \\
\hline $\mathrm{O}$ & 1 & 1.16 & $\begin{array}{l}\text { Posttranslational modification, protein } \\
\text { turnover, chaperones }\end{array}$ \\
\hline C & 0 & 0 & Energy production and conversion \\
\hline G & 0 & 0 & Carbohydrate transport and metabolism \\
\hline $\mathrm{E}$ & 0 & 0 & Amino acid transport and metabolism \\
\hline $\mathrm{F}$ & 2 & 2.33 & Nucleotide transport and metabolism \\
\hline $\mathrm{H}$ & 1 & 1.16 & Coenzyme transport and metabolism \\
\hline । & 0 & 0 & Lipid transport and metabolism \\
\hline$P$ & 0 & 0 & Inorganic ion transport and metabolism \\
\hline Q & 0 & 0 & $\begin{array}{l}\text { Secondary metabolites biosynthesis, } \\
\text { transport and catabolism }\end{array}$ \\
\hline $\mathrm{R}$ & 4 & 4.65 & General function prediction only \\
\hline S & 2 & 2.33 & Function unknown \\
\hline- & 72 & 83.72 & Not in COGs \\
\hline
\end{tabular}

The total is based on the total number of protein-coding genes in the annotated genome.

large vRNAP using CLUSTALW suggested that the RNA polymerase of vB_DshP-R1 contained four short motifs: TxxGR, A, B andC (data not shown). Combined with the homologous genes blasted from the NCBI database, these motifs were previously characterized in the stable binding of nucleic acid and in catalysis during the early transcriptional stage [25], while this polymerase shared only $<46 \%$ amino acid identity with its N4 homologs (Additional file 2: Table S2). In addition, this polymerase is an evolutionarily highly diverged enzyme [25] and can be used as a hypervariable region to distinguish different isolates [42]. For the two small vRNAPs, the genomic sequences had high similarity (78-83\% amino acid identity) and unsurprisingly contained the homologous catalytic domains in their structures. This suggested that phage 
vB_DshP-R1 might perform in a similar way to N4 phages in early and middle transcription, and indicated that the functions of these enzymes were conserved and typical for all available N4 phages.

\section{Comparisons with other N4like virus genomes}

Genomic organization (Figure 3) and intergenic homologies (Additional file 2: Table S2) among E. coli N4, Roseophage DSS3P2 and vB_DshP-R1 were present, which suggested that they were strongly homologous. Based on the alignment of the DNA pol amino acid sequences, phage vB_DshP-R1 closely clustered with the four representative N4 Roseophages ( $80 \%$ identity) described above (Figure 2). Analysis of all 86 putative CDSs blasted with the NCBI database, using the online auto setting, showed that most CDSs were highly homologous with four of these phages, except gene 45 and gene6 8 that were most similar to the Achromobacter phage JWDelta and Sulfitobacter phage pCB2047-B, respectively. In addition, $65 \%$ of analogous CDSs in vB_DshP-R1 were still present with unannotated features. From the genome maps in Figure 3, there were 33 ORFs $(57.63 \%$ of its genome length) that were identified as similar to the corresponding proteins of the typical coliphage N4 (mostly under $50 \%$ amino acid identity). In addition, 66 genes were highly homologous with Roseophage DSS3P2 (30-92\% amino acid identity). There were 19 CDSs uniquely present in the vB_DshP-R1 genome, including a putative deaminase (ORF60) that was homologous with trimeric dUTP diphosphatases of the Achromobacter phage JWDelta. Combining all these N4 phages from different species and distant environments, characteristics of the putative CDSs in these genomes revealed that they were almost consistent in genomic assemblies, including DNA replication, transcriptional regulation, DNA metabolism and structural gene modules (Figure 3). There were some genomic rearrangements that occurred in the genome of phage vB_DshP-R1, including gene 58, $59,72,73$ and 79 .

\section{Conclusions}

vB_DshP-R1 is the first virus to be identified infecting the sole species of the genus Dinoroseobacter in the Roseobacter clade. On the basis of its genomic analysis, this phage was found to be similar to the N4 phages, which are typical members of the Podoviridae. The genome appeared to have sets of putative functional modules in transcription and replication. Some of those sequences seemed to be preferably conserved in most N4 phages, although these phages were from distant habitats and infected diverse host bacteria. There were various unknown putative genes, about $65 \%$ of the ORFs (or more than $30 \%$ of the complete genome) in phage vB_DshP-R1. These apparent features improved our understanding of the conservation of $\mathrm{N} 4$ genomes and the specificity of phages infecting the Dinorosoebacter community.

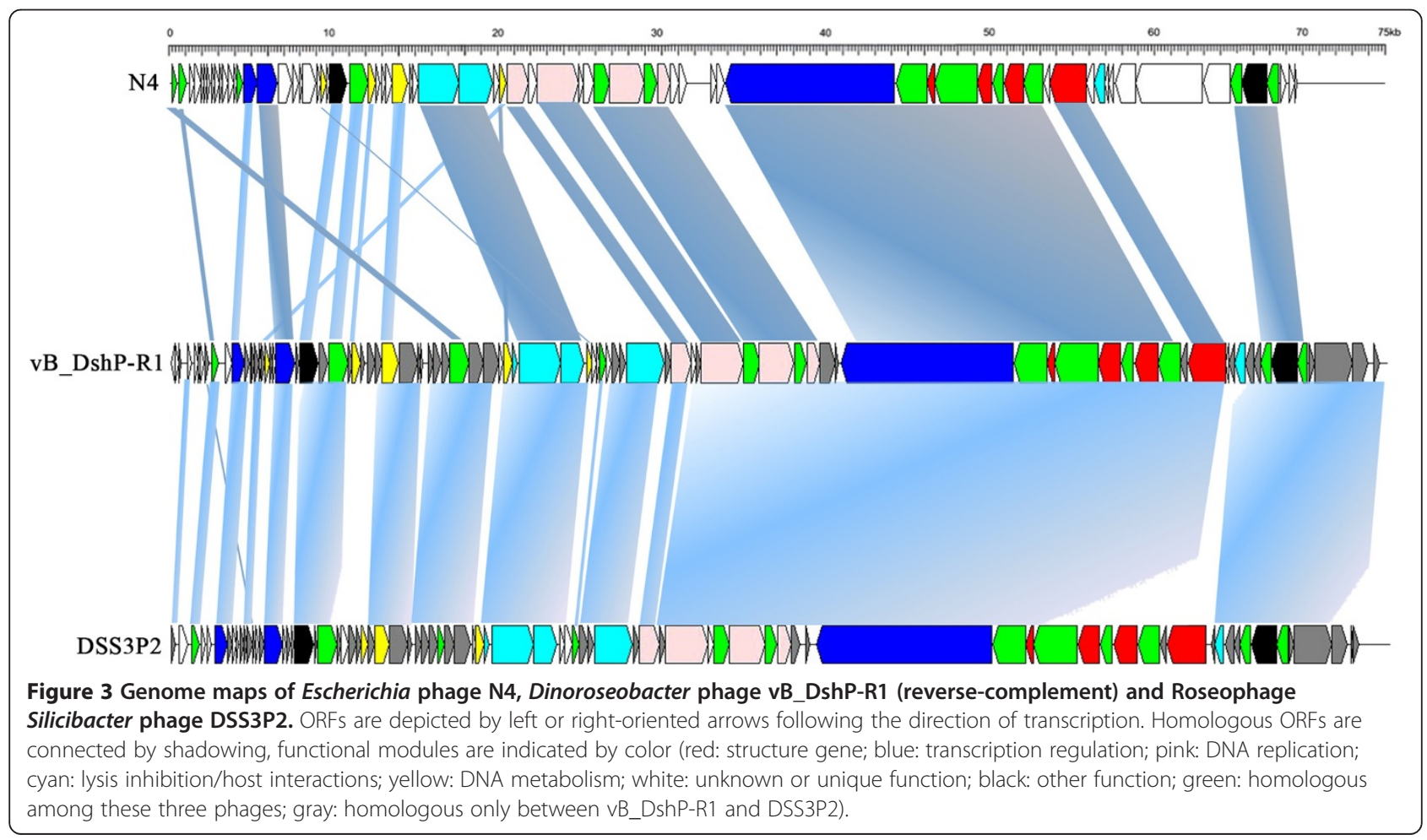




\section{Additional files}

Additional file 1: Table S1. Associated MIGS record.

Additional file 2: Table S2. Roseophage vB_DshP-R1 gene annotations*.

\section{Abbreviations}

BGI: Beijing genomics institute; CRISPR: Clustered regularly interspaced short palindromic repeat; GOLD: Genomes online database; IMG: Integrated microbial genomes; N4: Bacteriophage N4; ORF Finder: Open reading frame finder; RAST: Rapid annotation using subsystem technology; VRNAP: virion RNA polymerase.

\section{Competing interests}

The authors declare that they have no competing interests.

\section{Authors' contributions}

JJ drafted the manuscript, performed laboratory experiments, and analyzed the data. RZ and NJ together organized the study and drafted the manuscript. We all authors read and approved the final manuscript.

\section{Acknowledgments}

We thank Qiang Zheng, Kanagarajan Umapathy and Professor Yigang Tong of the Beijing Institute of Microbiology and Epidemiology for their useful suggestions. This work was supported by the 973 project (2013CB955700), the SOA Project (GASI-03-01-02-05) and the 863 Program (2012AA092003). R. Z. was supported by NSFC (41376132) and Fundamental Research Funds for the Central Universities (2012121052). We thank Professor John Hodgkiss of The University of Hong Kong for his assistance with English.

Received: 21 May 2014 Accepted: 23 November 2014 Published: 21 January 2015

\section{References}

1. Brinkhoff T, Giebel HA, Simon M. Diversity, ecology, and genomics of the Roseobacter clade: a short overview. Arch Microbiol. 2008; 189:531-39.

2. Wagner-Dobler I, Biebl H. Environmental biology of the marine Roseobacter lineage. Annu Rev Microbiol. 2006; 60:255-80.

3. Buchan A, Gonzalez JM, Moran MA. Overview of the marine roseobacter lineage. Appl Environ Microbiol. 2005; 71:5665-77.

4. Moran MA, Belas R, Schell MA, Gonzalez JM, Sun F, Sun S, Binder BJ, Edmonds J, Ye W, Orcutt B, Howard EC, Meile C, Palefsky W, Goesmann A, Ren Q, Paulsen I, Ulrich LE, Thompson LS, Saunders E, Buchan A. Ecological genomics of marine Roseobacters. Appl Environ Microbiol. 2007; 73:4559-69.

5. Moran MA, Miller WL. Resourceful heterotrophs make the most of light in the coastal ocean. Nat Rev Microbiol. 2007; 5:792-800.

6. Chen Y. Comparative genomics of methylated amine utilization by marine Roseobacter clade bacteria and development of functional gene markers (tmm, gmaS). Environ Microbiol. 2012; 14:2308-22.

7. Gonzalez JM, Simo R, Massana R, Covert JS, Casamayor EO, Pedros-Alio C, Moran MA. Bacterial community structure associated with a dimethylsulfoniopropionate-producing North Atlantic algal bloom. Appl Environ Microbiol. 2000; 66:4237-46.

8. Biebl H, Allgaier M, Tindall BJ, Koblizek M, Lunsdorf H, Pukall R, Wagner-Dobler I. Dinoroseobacter shibae gen. nov., sp. nov., a new aerobic phototrophic bacterium isolated from dinoflagellates. Int J Syst Evol Microbiol. 2005; 55:1089-96

9. Pan Y, Cembella AD, Quilliam MA. Cell cycle and toxin production in the benthic dinoflagellate Prorocentrum lima. Mar Biol. 1999; 134:541-49.

10. Wagner-Dobler I, Ballhausen B, Berger M, Brinkhoff T, Buchholz I, Bunk B, Cypionka H, Daniel R, Drepper T, Gerdts G, Hahnke S, Han C, Jahn D, Kalhoefer D, Kiss H, Klenk HP, Kyrpides N, Liebl W, Liesegang H, Meincke L, Pati A, Petersen J, Piekarski T, Pommerenke C, Pradella S, Pukall R, Rabus R, Stackebrandt E, Thole S, Thompson $L$, et al. The complete genome sequence of the algal symbiont Dinoroseobacter shibae: a hitchhiker's guide to life in the sea. ISME J. 2010; 4:61-77.

11. Biebl H, Wagner-Döbler I. Growth and bacteriochlorophyll a formation in taxonomically diverse aerobic anoxygenic phototrophic bacteria in chemostat culture: Influence of light regimen and starvation. Process Biochem. 2006; 41:2153-59.
12. Furch T, Preusse M, Tomasch J, Zech H, Wagner-Dobler I, Rabus R, Wittmann C. Metabolic fluxes in the central carbon metabolism of Dinoroseobacter shibae and Phaeobacter gallaeciensis, two members of the marine Roseobacter clade. BMC Microbiol. 2009; 9:209.

13. Holert J, Hahnke S, Cypionka H. Influence of light and anoxia on chemiosmotic energy conservation in Dinoroseobacter shibae. Environ Microbiol Rep. 2011; 3:136-41.

14. Paul C, Mausz MA, Pohnert G. A co-culturing/metabolomics approach to investigate chemically mediated interactions of planktonic organisms reveals influence of bacteria on diatom metabolism. Metabolomics. 2012; 9:349-59.

15. Horvath P, Barrangou R. CRISPR/Cas, the immune system of bacteria and archaea. Science. 2010; 327:167-70.

16. Garneau JE, Dupuis ME, Villion M, Romero DA, Barrangou R, Boyaval P, Fremaux C, Horvath P, Magadan AH, Moineau S. The CRISPR/Cas bacterial immune system cleaves bacteriophage and plasmid DNA. Nature. 2010; 468:67-71.

17. Bondy-Denomy J, Pawluk A, Maxwell KL, Davidson AR. Bacteriophage genes that inactivate the CRISPR/Cas bacterial immune system. Nature. 2013; 493:429-32.

18. Rohwer F, Segall A, Steward G, Seguritan V, Breitbart M, Wolven F, Azam F. The complete genomic sequence of the marine phage Roseophage $\mathrm{SIO} 1$ shares homology with nonmarine phages. Limnol Oceanogr. 2000; 45:408-18.

19. Angly F, Youle M, Nosrat B, Srinagesh S, Rodriguez-Brito B, McNairnie P, Deyanat-Yazdi G, Breitbart M, Rohwer F. Genomic analysis of multiple Roseophage SIO1 strains. Environ Microbiol. 2009; 11:2863-73.

20. Huang S, Zhang Y, Chen F, Jiao N. Complete genome sequence of a marine roseophage provides evidence into the evolution of gene transfer agents in alphaproteobacteria. Virol J. 2011; 8:124.

21. Zhao Y, Wang K, Jiao N, Chen F. Genome sequences of two novel phages infecting marine roseobacters. Environ Microbiol. 2009; 11:2055-64.

22. Kang I, Jang H, Hyun-Myung O, Cho J-C. Complete Genome Sequence of Celeribacter Bacteriophage P12053L. J Virol. 2012; 86:8339-40.

23. Schito GC. Development of coliphage N4: ultrastructural studies. J Virol. 1974; 13:186-96.

24. Choi KH, MCPartland J, Kaganman I, Bowman VD, Rothman-Denes LB, Rossmann MG. Insight into DNA and protein transport in doublestranded DNA viruses: the structure of bacteriophage N4. J Mol Biol. 2008; 378:726-36.

25. Kazmierczak KM, Davydova EK, Mustaev AA, Rothman-Denes LB. The phage N4 virion RNA polymerase catalytic domain is related to single-subunit RNA polymerases. EMBO J. 2002; 21:5815-23.

26. Chen F, Wang K, Huang S, Cai H, Zhao M, Jiao N, Wommack KE. Diverse and dynamic populations of cyanobacterial podoviruses in the Chesapeake Bay unveiled through DNA polymerase gene sequences. Environ Microbiol. 2009; 11:2884-92.

27. Nissimov JI, Worthy CA, Rooks P, Napier JA, Kimmance SA, Henn MR, Ogata $H$, Allen MJ. Draft genome sequence of the coccolithovirus EhV-84. Stand Genomic Sci. 2011; 5:1-11.

28. Thompson JD, Higgins DG, Gibson TJ. CLUSTAL W: improving the sensitivity of progressive multiple sequence alignment through sequence weighting, position-specific gap penalties and weight matrix choice. Nucleic Acids Res. 1994; 22:4673-80.

29. Tamura K, Stecher G, Peterson D, Filipski A, Kumar S. MEGA6: Molecular Evolutionary Genetics Analysis version 6.0. Mol Biol Evol. 2013; 30:2725-29.

30. Ashburner M, Ball CA, Blake JA, Botstein D, Butler H, Cherry JM, Davis AP, Dolinski K, Dwight SS, Eppig JT, Harris MA, Hill DP, Issel-Tarver L, Kasarskis A, Lewis S, Matese JC, Richardson JE, Ringwald M, Rubin GM, Sherlock G. Gene ontology: tool for the unification of biology. The Gene Ontology Consortium. Nat Genet. 2000; 25:25-9.

31. Suttle CA. Viruses in the sea. Nature. 2005; 437:356-61.

32. Suttle CA. Marine viruses-major players in the global ecosystem. Nat Rev Microbiol. 2007; 5:801-12.

33. Danovaro R, Corinaldesi C, Dell'anno A, Fuhrman JA, Middelburg JJ, Noble RT, Suttle CA. Marine viruses and global climate change. FEMS Microbiol Rev. 2011; 35:993-1034.

34. Suttle CA, Chen F. Mechanisms and Rates of Decay of Marine Viruses in Seawater. Appl Environ Microbiol. 1992; 58:3721-29.

35. Chen F, Wang K, Stewart J, Belas R. Induction of multiple prophages from a marine bacterium: a genomic approach. Appl Environ Microbiol. 2006; 72:4995-5001. 
36. Jamalludeen N, Kropinski AM, Johnson RP, Lingohr E, Harel J, Gyles CL. Complete genomic sequence of bacteriophage phiEcoM-GJ1, a novel phage that has myovirus morphology and a podovirus-like RNA polymerase. Appl Environ Microbiol. 2008; 74:516-25.

37. Li R, Zhu H, Ruan J, Qian W, Fang X, Shi Z, Li Y, Li S, Shan G, Kristiansen K, Li $\mathrm{S}$, Yang $\mathrm{H}$, Wang J, Wang J. De novo assembly of human genomes with massively parallel short read sequencing. Genome Res. 2010; 20:265-72.

38. Besemer J, Lomsadze A, Borodovsky M. GeneMarkS: a self-training method for prediction of gene starts in microbial genomes. Implications for finding sequence motifs in regulatory regions. Nucleic Acids Res. 2001; 29:2607-18.

39. Aziz RK, Bartels D, Best AA, DeJongh M, Disz T, Edwards RA, Formsma K, Gerdes S, Glass EM, Kubal M, Meyer F, Olsen GJ, Olson R, Osterman AL, Overbeek RA, McNeil LK, Paarmann D, Paczian T, Parrello B, Pusch GD, Reich C, Stevens R, Vassieva O, Vonstein V, Wilke A, Zagnitko O. The RAST Server: rapid annotations using subsystems technology. BMC Genomics. 2008; 9:75.

40. Lowe TM, Eddy SR. tRNAscan-SE: a program for improved detection of transfer RNA genes in genomic sequence. Nucleic Acids Res. 1997; 25:955-64.

41. Markowitz VM, Mavromatis K, Ivanova NN, Chen IM, Chu K, Kyrpides NC. IMG ER: a system for microbial genome annotation expert review and curation. Bioinformatics. 2009; 25:2271-78.

42. Kulikov E, Kropinski AM, Golomidova A, Lingohr E, Govorun V, Serebryakova M, Prokhorov N, Letarova M, Manykin A, Strotskaya A, Letarov A. Isolation and characterization of a novel indigenous intestinal N4-related coliphage vB_EcoP_G7C. Virology. 2012; 426:93-9.

doi:10.1186/1944-3277-10-6

Cite this article as: $\mathrm{Ji}$ et al:: Complete genome sequence of Roseophage VB_DshP-R1, which infects Dinoroseobacter shibae DFL12. Standards in Genomic Sciences 2015 10:6.

\section{Submit your next manuscript to BioMed Central and take full advantage of:}

- Convenient online submission

- Thorough peer review

- No space constraints or color figure charges

- Immediate publication on acceptance

- Inclusion in PubMed, CAS, Scopus and Google Scholar

- Research which is freely available for redistribution 